Article

\title{
Variation of Deoxynivalenol Levels in Corn and Its Products Available in Retail Markets of Punjab, Pakistan, and Estimation of Risk Assessment
}

\author{
Shahzad Zafar Iqbal ${ }^{1, *(\mathbb{D}}$, Ahmad Faizal Abdull Razis ${ }^{2,3, *(\mathbb{D}}$, Sunusi Usman ${ }^{3}{ }^{(\mathbb{D}}$, Nada Basheir Ali ${ }^{2}$ and \\ Muhammad Rafique Asi ${ }^{4}$
}

check for

updates

Citation: Iqbal, S.Z.; Abdull Razis, A.F.; Usman, S.; Ali, N.B.; Asi, M.R. Variation of Deoxynivalenol Levels in Corn and Its Products Available in Retail Markets of Punjab, Pakistan, and Estimation of Risk Assessment. Toxins 2021, 13, 296. https://doi.org/ $10.3390 /$ toxins 13050296

Received: 30 January 2021

Accepted: 15 March 2021

Published: 22 April 2021

Publisher's Note: MDPI stays neutral with regard to jurisdictional claims in published maps and institutional affiliations.

\section{Copyright: (c) 2021 by the authors.} Licensee MDPI, Basel, Switzerland. This article is an open access article distributed under the terms and conditions of the Creative Commons Attribution (CC BY) license (https:// creativecommons.org/licenses/by/ $4.0 /)$.
1 Department of Applied Chemistry, Government College University Faisalabad, Faisalabad 38000, Pakistan

2 Department of Food Science, Faculty of Food Science and Technology, Universiti Putra Malaysia (UPM), 43400 UPM Serdang, Selangor, Malaysia; nada44basher@gmail.com

3 Natural Medicines and Products Research Laboratory, Institute of Bioscience, Universiti Putra Malaysia (UPM), 43400 UPM Serdang, Selangor, Malaysia; usunusi.bch@buk.edu.ng

4 Food Toxicology Lab, Nuclear Institute for Agriculture and Biology (NIAB), Faisalabad 38000, Pakistan; asimuhammad@yahoo.co.uk

* Correspondence: shahzad10542005@yahoo.com (S.Z.I.); madfaizal@upm.edu.my (A.F.A.R.); Tel.: +92-300-7684577 (S.Z.I.); Tel.: +60-39-7693073 (A.F.A.R.)

\begin{abstract}
This study investigated the natural incidence of deoxynivalenol (DON) in corn and corn products from corn-producing districts of Punjab, Pakistan. The analysis was carried out using high performance liquid chromatography (HPLC) with UV detector and immunoaffinity cleanup columns. The detection limit (LOD) and limit of quantification were 25 and $50 \mu \mathrm{g} / \mathrm{kg}$, respectively. A total of 1220 samples of corn and corn products were analyzed to detect DON, and $539(44.2 \%)$ samples were observed to be contaminated with DON ( $n \geq$ LOD). Furthermore, 92 (7.5\%) samples of corn and corn products had DON levels that were higher than the proposed limits of the EU. The data are significantly different from a normal distribution of DON in samples of corn and corn products from different locations $(p<0.05)$ for Shapiro-Wilk and Kolmogorov-Smirnov values. However, a significant difference in DON levels was found between corn and corn-derived products $(p \leq 0.05)$. The lowest and highest exposures, and hazard quotient (HQ) values of 0.92 and $9.68 \mu \mathrm{g} / \mathrm{kg}$ bw/day, were documented in corn flour samples.
\end{abstract}

Keywords: DON; corn; corn products; exposure; risk assessment

Key Contribution: A total of 1220 samples of corn and corn products from three districts of Punjab were analyzed for DON. In all, 539 samples (44.2\%) of corn and corn products were found to be positive with DON ( $n \geq$ LOD), while 92 samples (7.5\%) of corn and corn products contained levels of DON greater than the proposed limits of the EU $(1000 \mu \mathrm{g} / \mathrm{kg} ; 750 \mu \mathrm{g} / \mathrm{kg})$. The lowest and highest exposures, and HQ levels of 0.92 and $9.68 \mu \mathrm{g} / \mathrm{kg}$ bw/day, were documented in corn flour samples.

\section{Introduction}

Corn (Zea mays) is the third most produced crop in Pakistan after wheat and rice. Its share of the country's total cereal cultivation area is $8.5 \%$; it is responsible for $2.2 \%$ of value added in the agriculture sector and $0.4 \%$ of gross domestic product (GDP). Corn plays a vital role in the country's economy through its multiple domestic, commercial and industrial uses. In 2017-2018, corn production was estimated at 5.8 million tons, 3\% higher than the previous year, reflecting its in-country demand. Hybrid corn is cultivated in about $40 \%$ of the corn-growing area, and its share in total corn production is around $70 \%$. About $65 \%$ of corn is utilized in the poultry industry, $10 \%$ is used in dairy feed, $15 \%$ is used in wet milling and the remainder is used for human consumption and seeds [1]. Corn is a 
cereal that is susceptible to attacks by fungi and the subsequent production of mycotoxins (e.g., deoxynivalenol (DON)) [2,3].

Mycotoxins are recognized as secondary metabolites and are produced by fungi, mainly Aspergillus, Penicillium, Fusarium, Alternaria and Cladosporium [4-7]. Fusarium is widely dispersed in nature and causes spoilage or deterioration of food and feeds [8]. DON, also identified as vomitoxin, is a secondary fungal metabolite to the class of trichothecenes and is produced by the genus Fusarium, especially F. graminearum [9-13]. Previous studies have documented the toxic effects of trichothecenes, such as feed refusal, hemorrhage, vomiting, diarrhea, anemia and immunosuppression [14-16].

In a previous study by Raza et al. [17], 63 of 100 samples from rural, semirural and urban areas in the central cities of Punjab, Pakistan, were found to be contaminated with DON. The results indicated that $63 \%$ of corn samples were contaminated with DON, and from these samples, almost $66 \%$ had levels higher than $1250 \mu \mathrm{g} / \mathrm{kg}$. Furthermore, $49.2 \%$ of samples had levels higher than $1401 \mu \mathrm{g} / \mathrm{kg}$. The results indicated that the levels were higher in samples from rural areas, both in corn $(1512 \mu \mathrm{g} / \mathrm{kg})$ and wheat $(1585 \mu \mathrm{g} / \mathrm{kg})$. Similarly, the effect of seasonal variation on the levels of DON in wheat and corn samples was investigated in Punjab, Pakistan [18]. The results showed that 87 (61.2\%) samples of corn and corn products from summer and 57 samples (44.5\%) from winter were contaminated, with concentrations ranging from 50 to $2967 \mu \mathrm{g} / \mathrm{kg}$ and 50 to $2490 \mu \mathrm{g} / \mathrm{kg}$, respectively.

Different countries and organizations have established maximum limits for DON in raw and processed cereal products. The Codex Alimentarius Commission has established a permissible limit of $2000 \mu \mathrm{g} / \mathrm{kg}$ in raw barley, wheat and corn. Similarly, the EU has also established a limit of $2000 \mu \mathrm{g} / \mathrm{kg}$ in unprocessed wheat and oats. However, a permissible legal limit of $1000 \mu \mathrm{g} / \mathrm{kg}$ exists for raw or unprocessed cereals, $750 \mu \mathrm{g} / \mathrm{kg}$ for foodstuffs intended for consumers and dry pasta and $200 \mu \mathrm{g} / \mathrm{kg}$ for snacks and breakfast cereals for children [19]. The proposed daily intake limit for DON is $1 \mu \mathrm{g} / \mathrm{kg}$ bw.

Pakistan is located in the tropics, and therefore, the environmental conditions encourage fungal growth and production [5,20]. Although corn is a major cash crop, previous studies have shown that this substrate is more vulnerable to fungi attack and contamination. However, there is not enough information available on the prevalence of DON in corn-derived foods in Pakistan. Consequently, the existing study was designed to examine the incidence of levels of DON in corn and corn-derived products and compare these levels with EU-recommended regulations. The assessment of levels of DON in corn and corn products will also help disseminate this information to farmers, traders and other stakeholders in Pakistan.

\section{Results}

\subsection{Method Validation}

The recovery analysis of DON in corn and corn products is presented in Table 1 . The recoveries were in the range of $81.3 \%$ to $91.0 \%$, and the relative standard deviation varied from $11 \%$ to $28 \%$. The detection limit (LOD) and limit of quantification (LOQ) were 25 and $50 \mu \mathrm{g} / \mathrm{kg}$, respectively. The straight-line equation was constructed, and the coefficient of determination (0.9992) was obtained, as shown in Supplementary Figure S1.

\subsection{Incidence of DON in Corn and Corn Products}

The occurrence of DON in 1220 samples of corn and corn products (449 samples from Gujranwala, 378 from Hafizabad and 393 from Sheikhupura) is presented in Tables 2 and 3. In total, 539 samples of corn and corn products $(44.2 \%)$ were found to be positive $(n \geq \operatorname{LOD})$ with DON. Of the 449 samples of corn and corn products from Gujranwala, 197 (43.9\%) were found to be positive with DON (Table 2). 
Table 1. Recovery percentage of deoxynivalenol (DON) in corn and corn products.

\begin{tabular}{|c|c|c|c|c|c|c|c|c|c|c|c|c|c|c|c|c|}
\hline \multirow{3}{*}{$\begin{array}{l}\text { DON } \\
\text { Level }\end{array}$} & \multicolumn{4}{|c|}{ Corn (Mix) } & \multicolumn{4}{|c|}{ Corn Flour } & \multicolumn{4}{|c|}{ Corn Bread } & \multicolumn{4}{|c|}{ Sweet Corn } \\
\hline & \multirow{2}{*}{$\begin{array}{c}\text { Recovery } \\
(\%)\end{array}$} & \multirow{2}{*}{$\begin{array}{c}\text { RSD } \\
(\%)\end{array}$} & \multicolumn{2}{|c|}{ Precision (\%) } & \multirow{2}{*}{$\begin{array}{c}\text { Recovery } \\
(\%)\end{array}$} & \multirow{2}{*}{$\begin{array}{c}\text { RSD } \\
(\%)\end{array}$} & \multicolumn{2}{|c|}{ Precision (\%) } & \multirow{2}{*}{$\begin{array}{c}\text { Recovery } \\
(\%)\end{array}$} & \multirow{2}{*}{$\begin{array}{c}\text { RSD } \\
(\%)\end{array}$} & \multicolumn{2}{|c|}{ Precision (\%) } & \multirow{2}{*}{$\begin{array}{c}\text { Recovery } \\
(\%)\end{array}$} & \multirow{2}{*}{$\begin{array}{c}\text { RSD } \\
(\%)\end{array}$} & \multicolumn{2}{|c|}{ Precision (\%) } \\
\hline & & & $\operatorname{Rep}^{a}$ & Reprod $^{b}$ & & & $\operatorname{Rep}^{a}$ & Reprod $^{b}$ & & & $\operatorname{Rep}^{a}$ & $\operatorname{Reprod}^{b}$ & & & $\operatorname{Rep}^{a}$ & Reprod $^{b}$ \\
\hline 150 & 89.5 & 11 & 18 & 19 & 86.5 & 14 & 09 & 15 & 83.5 & 18 & 15 & 26 & 89.5 & 17 & 14 & 17 \\
\hline 300 & 88.0 & 22 & 15 & 22 & 87.4 & 17 & 16 & 22 & 90.5 & 23 & 10 & 18 & 89.5 & 15 & 9 & 21 \\
\hline 400 & 91.0 & 13 & 18 & 24 & 90.9 & 12 & 14 & 20 & 89.5 & 22 & 12 & 22 & 88.4 & 19 & 17 & 26 \\
\hline 800 & 88.8 & 23 & 10 & 22 & 86.1 & 16 & 18 & 26 & 88.4 & 21 & 15 & 20 & 85.2 & 21 & 15 & 24 \\
\hline 3000 & 85.0 & 21 & 18 & 28 & 84.0 & 20 & 20 & 27 & 85.5 & 20 & 18 & 27 & 81.3 & 28 & 18 & 28 \\
\hline
\end{tabular}

$\mathrm{RSD}=$ relative standard deviation, $\mathrm{LOD}=25 \mu \mathrm{g} / \mathrm{kg}, \mathrm{LOQ}=50 \mu \mathrm{g} / \mathrm{kg}$, a = repeatability, $\mathrm{b}=$ reproducibility. 
Table 2. Occurrence of DON in corn and corn products from Gujranwala, Punjab, Pakistan.

\begin{tabular}{ccccc}
\hline Sample Type & $\begin{array}{c}\text { Samples } \\
\mathbf{N}\end{array}$ & $\begin{array}{c}\text { Positive } \\
\boldsymbol{N}(\mathbf{\%})\end{array}$ & $\begin{array}{c}\text { Mean } \\
(\mu \mathrm{g} / \mathbf{k g}) \pm \mathbf{S . D} .\end{array}$ & $\begin{array}{c}\text { Range } \\
(\boldsymbol{\mu g} / \mathbf{k g})\end{array}$ \\
\hline Corn 1 & 40 & $18(45.0)$ & $1256.2 \pm 124.5$ & $25-5687.5$ \\
\hline Corn 2 & 45 & $22(48.9)$ & $1126.2 \pm 90.8$ & $25-5568.6$ \\
\hline Corn 3 & 54 & $15(27.8)$ & $1049.7 \pm 110.5$ & $25-5678.5$ \\
\hline Corn 4 & 41 & $22(53.7)$ & $909.8 \pm 120.5$ & $25-4550.5$ \\
\hline Corn flour & 60 & $34(57.6)$ & $854.7 \pm 40.7$ & $25-8990.5$ \\
\hline Sweet corn & 83 & $30(36.1)$ & $556.5 \pm 80.6$ & $25-4550.5$ \\
\hline Corn bread & 35 & $18(51.4)$ & $86.6 \pm 14.5$ & $25-450.5$ \\
\hline Corn oil & 56 & $22(39.3)$ & $88.8 \pm 15.5$ & $25-980.5$ \\
\hline Popcorn & 35 & $16(45.7$ & $41.4 \pm 10.5$ & $25-95.5$ \\
\hline Total & 449 & $197(43.9)$ & & $25-8990.5$ \\
\hline
\end{tabular}

Corn 1 = corn variety; Corn 2 = corn variety; Corn 3 = corn variety; Corn 4 = corn variety, $N(\%)=n$ (percentage of samples), $\mathrm{LOD}=25 \mu \mathrm{g} / \mathrm{kg}$.

Table 3. Occurrence of DON in corn and corn products from Sheikhupura, Punjab, Pakistan.

\begin{tabular}{ccccc}
\hline Sample Type & $\begin{array}{c}\text { Samples } \\
\boldsymbol{N}\end{array}$ & $\begin{array}{c}\text { Positive } \\
\boldsymbol{N}(\mathbf{\%})\end{array}$ & $\begin{array}{c}\text { Mean } \\
(\mu \mathrm{g} / \mathbf{k g}) \pm \mathbf{S . D} .\end{array}$ & $\begin{array}{c}\text { Range } \\
(\boldsymbol{\mu g} / \mathbf{k g})\end{array}$ \\
\hline Corn 1 & 48 & $15(37.5$ & $1187.3 \pm 230$ & $25-6660.5$ \\
\hline Corn 2 & 48 & $18(37.5)$ & $1081.6 \pm 145.5$ & $25-6590.6$ \\
\hline Corn 3 & 56 & $25(44.6)$ & $808.2 \pm 60.5$ & $25-5640.5$ \\
\hline Corn 4 & 46 & $22(47.8)$ & $1489.4 \pm 180.5$ & $25-5540.5$ \\
\hline Corn flour & 61 & $25(41.0)$ & $1030.8 \pm 170.5$ & $25-7860.5$ \\
\hline Sweet corn & 38 & $18(47.4)$ & $471.1 \pm 30.5$ & $25-2345.5$ \\
\hline Corn bread & 39 & $17(43.6)$ & $97.3 \pm 15.5$ & $25-500.5$ \\
\hline Corn oil & 30 & $23(76.7)$ & $88.3 \pm 9.5$ & $25-540.5$ \\
\hline Popcorn & 35 & $13(37.1)$ & $42.1 \pm 4.5$ & $25-90.5$ \\
\hline Total & 393 & $176(44.8)$ & & $25-7860$ \\
\hline
\end{tabular}

Corn 1 = corn variety; Corn 2 = corn variety; Corn 3 = corn variety; Corn $4=$ corn variety, $N(\%)=n$ (percentage of samples), $\mathrm{LOD}=25 \mu \mathrm{g} / \mathrm{kg}$.

The maximum average of $1256.2 \pm 124.5 \mu \mathrm{g} / \mathrm{kg}$ of DON was found in corn type $1 \mathrm{sam}$ ples and varied from 25 to $5687.5 \mu \mathrm{g} / \mathrm{kg}$. Table 4 shows that $166(43.9 \%)$ of the 378 samples of corn and corn products from Hafizabad were positive, with the maximum average $(1489.4 \pm 190.8 \mu \mathrm{g} / \mathrm{kg})$ in corn type 4 samples ranging from 25 to $5540.5 \mu \mathrm{g} / \mathrm{kg}$. Furthermore, $176(44.8 \%)$ of the 393 samples of corn and corn products from Sheikhupura were found to be contaminated with DON, and the maximum average $(1489.4 \pm 180.5 \mu \mathrm{g} / \mathrm{kg})$ was found in corn type 4 samples, with concentration ranging from 25 to $5540.5 \mu \mathrm{g} / \mathrm{kg}$. About $92(7.5 \%)$ samples of corn and corn products were found to be contaminated with DON at levels higher than the EU's proposed limits [19], as represented in Figure 1.

The data are significantly different from a normal distribution of DON in different types of corn and corn products from different locations, considering the high values of skewness and kurtosis and $p \leq 0.00$ for the Shapiro-Wilk and Kolmogorov-Smirnov values. The ANOVA of DON levels in different corn and corn products was statistically significant $(p \leq 0.000)$. The amounts of DON in corn and corn products from different locations were nonsignificant ( $p \geq 0.05$ ), as shown in Table 5. Furthermore, Table 6 shows the least significant difference (LSD) of the different types of corn and corn products. 
Table 4. Occurrence of DON in corn and corn products from Hafizabad, Punjab, Pakistan.

\begin{tabular}{ccccc}
\hline Sample Type & $\begin{array}{c}\text { Samples } \\
\boldsymbol{N}\end{array}$ & $\begin{array}{c}\text { Positive } \\
\boldsymbol{N}(\mathbf{\%})\end{array}$ & $\begin{array}{c}\text { Mean } \\
(\mu \mathrm{g} / \mathbf{k g}) \pm \mathbf{S . D} .\end{array}$ & $\begin{array}{c}\text { Range } \\
(\boldsymbol{\mu g} / \mathbf{k g})\end{array}$ \\
\hline Corn 1 & 32 & $16(50.0)$ & $1187.3 \pm 210.5$ & $25-6660.5$ \\
\hline Corn 2 & 55 & $19(34.5)$ & $1081.6 \pm 140.3$ & $25-6590.6$ \\
\hline Corn 3 & 40 & $21(52.5)$ & $808.2 \pm 70.5$ & $25-5640.5$ \\
\hline Corn 4 & 30 & $14(46.7)$ & $1489.4 \pm 190.8$ & $25-5540.5$ \\
\hline Corn flour & 45 & $21(46.7)$ & $1030.8 \pm 105.4$ & $25-7860.5$ \\
\hline Sweet corn & 40 & $17(42.5)$ & $471.1 \pm 20.5$ & $25-2345.5$ \\
\hline Corn bread & 55 & $22(40.0)$ & $97.3 \pm 15.5$ & $25-500.5$ \\
\hline Corn oil & 45 & $20(44.4)$ & $88.3 \pm 9.5$ & $25-540.5$ \\
\hline Popcorn & 36 & $16(44.4)$ & $42.2 \pm 4.5$ & $25-80.5$ \\
\hline Total & 378 & $166(43.9)$ & & $25-7860.5$ \\
\hline
\end{tabular}

Corn 1 = corn variety; Corn 2 = corn variety; Corn 3 = corn variety; Corn $4=$ corn variety, $N(\%)=n$ (percentage of samples), $\mathrm{LOD}=25 \mu \mathrm{g} / \mathrm{kg}$.

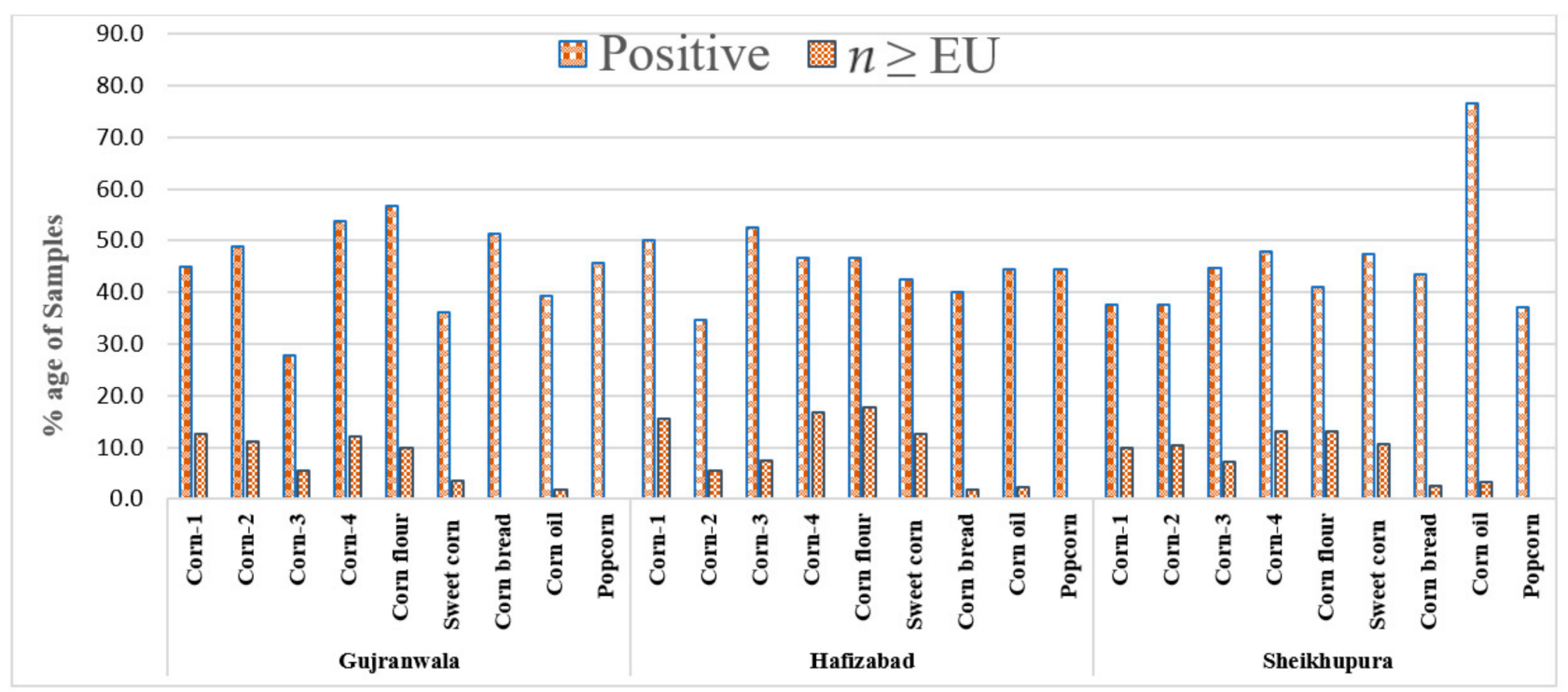

Figure 1. Percentage of samples of corn and corn products having levels of deoxynivalenol (DON) higher than the EU's recommended limits (1000 $\mu \mathrm{g} / \mathrm{kg}$ for unprocessed corn and $750 \mu \mathrm{g} / \mathrm{kg}$ for foodstuffs).

Table 5. ANOVA of DON levels in corn and corn products from various locations.

\begin{tabular}{ccccccc}
\hline & & $\begin{array}{c}\text { Sum of } \\
\text { Squares }\end{array}$ & df & Mean Square & F & Sig \\
\hline DON Level & Between groups & $96,192,972.7$ & 8 & $12,024,121.6$ & 8.132 & 0.000 \\
\hline & Within groups & $783,676,623.6$ & 530 & $1,478,635.1$ & & \\
\hline Location & Betwl & $879,869,596.4$ & 538 & & & \\
\hline & Within groups & 367.4 & 530 & 0.592 & 0.854 & 0.555 \\
\hline & Total & 372.2 & 538 & 0.693 & & \\
\hline
\end{tabular}


Table 6. Least significant difference (LSD) analysis of different types of corn and corn products within groups of samples.

\begin{tabular}{|c|c|c|c|c|c|}
\hline & & Corn Products & Mean Difference & Std. Error & Significance \\
\hline \multirow{4}{*}{\multicolumn{2}{|c|}{ Don Level }} & Sweet corn & 629.92 & 230.05 & 0.006 \\
\hline & & Corn bread & 1066.63 & 236.89 & 0.000 \\
\hline & & Corn oil & 1073.58 & 230.05 & 0.000 \\
\hline & & Popcorn & 1130.06 & 251.06 & 0.000 \\
\hline \multirow{4}{*}{\multicolumn{2}{|c|}{ Corn 2}} & Sweet corn & 542.88 & 218.65 & 0.013 \\
\hline & & Corn bread & 979.59 & 225.83 & 0.000 \\
\hline & & Corn oil & 986.53 & 218.65 & 0.000 \\
\hline & & Popcorn & 1043.03 & 240.66 & 0.000 \\
\hline \multirow{3}{*}{\multicolumn{2}{|c|}{ Corn 3}} & Corn bread & 842.21 & 224.01 & 0.000 \\
\hline & & Corn oil & 849.16 & 216.76 & 0.000 \\
\hline & & Popcorn & 9.05 .65 & 238.95 & 0.000 \\
\hline \multirow{4}{*}{\multicolumn{2}{|c|}{ Corn 4}} & Sweet corn & 483.11 & 219.64 & 0.028 \\
\hline & & Corn bread & 919.82 & 226.79 & 0.000 \\
\hline & & Corn oil & 926.77 & 219.64 & 0.000 \\
\hline & & Popcorn & 983.26 & 241.56 & 0.000 \\
\hline \multirow{3}{*}{\multicolumn{2}{|c|}{ Corn flour }} & Corn bread & 772.55 & 210.76 & 0.000 \\
\hline & & Corn oil & 779.50 & 203.05 & 0.000 \\
\hline & & Corn popcorn & 8.35 .99 & 226.58 & 0.000 \\
\hline \multirow{6}{*}{\multicolumn{2}{|c|}{ Sweet corn }} & Corn type 1 & -629.91 & 230.05 & 0.006 \\
\hline & & Corn type 2 & -542.88 & 218.65 & 0.013 \\
\hline & & Corn type 4 & -483.11 & 219.64 & 0.028 \\
\hline & & Corn bread & 436.70 & 220.65 & 0.048 \\
\hline & & Corn oil & 443.65 & 213.29 & 0.038 \\
\hline & & Popcorn & 500.15 & 235.81 & 0.034 \\
\hline \multirow{6}{*}{\multicolumn{2}{|c|}{ Corn bread }} & Corn type 1 & -1066.62 & 236.89 & 0.000 \\
\hline & & Corn type 2 & -979.59 & 225.83 & 0.000 \\
\hline & & Corn type 3 & -842.21 & 224.01 & 0.000 \\
\hline & & Corn type 4 & -919.82 & 226.79 & 0.000 \\
\hline & & Corn flour & -772.55 & 210.76 & 0.000 \\
\hline & & Sweet corn & -436.70 & 220.65 & 0.048 \\
\hline \multirow{6}{*}{\multicolumn{2}{|c|}{ Corn oil }} & Corn type 1 & -1073.57 & 230.05 & 0.000 \\
\hline & & Corn type 2 & -986.53 & 218.65 & 0.000 \\
\hline & & Corn type 3 & -849.15 & 216.76 & 0.000 \\
\hline & & Corn type 4 & -926.73 & 219.64 & 0.000 \\
\hline & & Corn flour & -779.50 & 203.05 & 0.000 \\
\hline & & Sweet corn & -443.65 & 213.29 & 0.038 \\
\hline \multirow{6}{*}{\multicolumn{2}{|c|}{ Popcorn }} & Corn type 1 & -1130.06 & 251.06 & 0.000 \\
\hline & & Corn type 2 & -1043.03 & 240.66 & 0.000 \\
\hline & & Corn type 3 & -905.65 & 238.95 & 0.000 \\
\hline & & Corn type 4 & -983.26 & 241.56 & 0.000 \\
\hline & & Corn flour & -835.99 & 226.58 & 0.000 \\
\hline & & Sweet corn & -500.15 & 235.81 & 0.034 \\
\hline
\end{tabular}




\subsection{Estimation of Exposure Assessment of DON in Corn Flour}

The assessment of exposure of DON levels in corn flour from different locations is presented in Table 7. The highest DON exposure was $9.68 \mu \mathrm{g} / \mathrm{kg}$ bw/day, and the lowest exposure was $0.92 \mu \mathrm{g} / \mathrm{kg}$ bw / day in corn flour samples from the Gujranwala district.

Table 7. Exposure assessment of DON in corn flour from corn-producing cities of Punjab, Pakistan.

\begin{tabular}{|c|c|c|c|c|c|c|c|c|c|c|c|c|c|}
\hline & \multirow{3}{*}{$\begin{array}{l}\text { Consum- } \\
\text { ption } \\
(\mathrm{kg})\end{array}$} & \multicolumn{4}{|c|}{ Gujranwala } & \multicolumn{4}{|c|}{ Hafizabad } & \multicolumn{4}{|c|}{ Sheikhupura } \\
\hline & & \multicolumn{2}{|c|}{ DON Levels } & \multicolumn{2}{|c|}{ Exposure } & \multicolumn{2}{|c|}{ DON Levels } & \multicolumn{2}{|c|}{ Exposure } & \multicolumn{2}{|c|}{ DON Levels } & \multicolumn{2}{|c|}{ Exposure } \\
\hline & & $\begin{array}{l}\text { Mean } \\
\mu \mathrm{g} / \mathrm{kg}\end{array}$ & $\begin{array}{c}\text { Highest } \\
\text { Level } \\
\mu \mathrm{g} / \mathrm{kg}\end{array}$ & $\begin{array}{c}\text { Mean } \\
\mu \mathrm{g} / \mathrm{kg} \\
\text { bw/day }\end{array}$ & $\begin{array}{c}\text { Highest } \\
\mu \mathrm{g} / \mathrm{kg} \\
\text { bw/day }\end{array}$ & $\begin{array}{l}\text { Mean } \\
\mu \mathrm{g} / \mathrm{kg}\end{array}$ & $\begin{array}{c}\text { Highest } \\
\text { Level } \\
\mu \mathrm{g} / \mathrm{kg}\end{array}$ & $\begin{array}{c}\text { Mean } \\
\mu \mathrm{g} / \mathrm{kg} \\
\text { bw/day }\end{array}$ & $\begin{array}{c}\text { Highest } \\
\mu \mathrm{g} / \mathrm{kg} \\
\text { bw/day }\end{array}$ & $\begin{array}{l}\text { Mean } \\
\mu \mathrm{g} / \mathrm{kg}\end{array}$ & $\begin{array}{c}\text { Highest } \\
\text { Level } \\
\mu \mathrm{g} / \mathrm{kg}\end{array}$ & $\begin{array}{c}\text { Mean } \\
\mu \mathrm{g} / \mathrm{kg} \\
\text { bw/day }\end{array}$ & $\begin{array}{c}\text { Highest } \\
\mu \mathrm{g} / \mathrm{kg} \\
\text { bw/day }\end{array}$ \\
\hline $\begin{array}{l}\text { Corn } \\
\text { flour }\end{array}$ & 0.07 & 854.7 & 8990.5 & 0.92 & 9.68 & 1030.8 & 7860.5 & 1.11 & 8.47 & 1030.8 & 7860.5 & 1.11 & 8.47 \\
\hline $\mathrm{HQ}^{1}$ & & & & 0.92 & & & & 1.11 & & & & 1.11 & \\
\hline $\mathrm{HQ}^{2}$ & & & & & 9.68 & & & & 8.47 & & & & 8.47 \\
\hline
\end{tabular}

$\mathrm{HQ}^{1}=$ mean level of DON, $\mathrm{HQ}^{2}=$ highest level of DON.

\section{Discussion}

\subsection{Method Validation}

The results showed that the analytical parameters such as accuracy and precision of DON in corn and corn products were within the European Commission's recommended guidelines [21,22]. According to the guidelines, the recoveries of DON should be within the range of $60 \%$ to $110 \%$, and the repeatability and reproducibility should be $\leq 20 \%$ and $\leq 40 \%$, respectively. Furthermore, for DON values $>500 \mu \mathrm{g} / \mathrm{kg}$, the recommendations are $70 \%$ to $120 \%$ recoveries, and repeatability and reproducibility must be less than $20 \%$ and $40 \%$, respectively [22,23]. The determination coefficient was $\geq 0.999$, and LOD and LOQ were 25 and $50 \mu \mathrm{g} / \mathrm{kg}$, respectively. The coefficient of determination was quite similar to the value from our previous study by Iqbal et al. [18]. However, the LOD and LOQ are much lower in the current study. Ok et al. [23] documented a coefficient of determination of $\geq 0.999$ and found LOD and LOQ values in ranges of 6.4 to $10.0 \mu \mathrm{g} / \mathrm{kg}$ and 21.3 to $33.5 \mu \mathrm{g} / \mathrm{kg}$, respectively. Yang et al. [24] demonstrated the LOD of $12.2 \mu \mathrm{g} / \mathrm{kg}$ for DON in corn samples using SPE cleanup. In another study, relatively high LOD and LOQ values for DON-i.e., 30 and $40 \mu \mathrm{g} / \mathrm{kg}$ - were documented in milling fractions of wheat using multifunctional column cleanup [25]. Golge and Kabak [26] determined LOQ values of 46.90 to $72.30 \mu \mathrm{g} / \mathrm{kg}$ of DON in various cereal products, higher than the LOQ of the present study.

\subsection{Incidence of DON in Corn and Corn Products}

The results have shown comparatively high levels of DON in corn and corn products from three districts, i.e., Gujranwala, Hafizabad and Sheikhupura in Punjab, Pakistan. In our previous study [18], we investigated the seasonal variation of DON levels in corn and corn products and documented that samples from summer have a higher incidence-i.e., $87(61.2 \%)$ - than the samples from winter $(44.5 \%)$. The maximum average observed was $1434.8 \pm 25.5 \mu \mathrm{g} / \mathrm{kg}$ in corn flour samples from summer, and the lowest mean level was $620.8 \pm 17.8 \mu \mathrm{g} / \mathrm{kg}$ in corn bread from winter. A high incidence level of DON compared to the present results was observed in Spain, where almost $68 \%$ of commercial corn-based food samples were found to be positive, with levels ranging from 29 to $195 \mu \mathrm{g} / \mathrm{kg}$ [27]. In Turkey, Golge and Kabak [26] assessed 13 wheat samples (58 to $1092 \mu \mathrm{g} / \mathrm{kg}$ ), 3 barley samples (138 to $973 \mu \mathrm{g} / \mathrm{kg}$ ), 7 paddy rice samples (136 to $256 \mu \mathrm{g} / \mathrm{kg}$ ), 3 wheat flour samples (92 to $151 \mu \mathrm{g} / \mathrm{kg}$ ), 2 biscuit samples (31.2 to $71.3 \mu \mathrm{g} / \mathrm{kg}$ ) and 1 pasta sample $(59.3 \mu \mathrm{g} / \mathrm{kg}$ ). However, two corn samples were found to be contaminated with DON (313 to $331 \mu \mathrm{g} / \mathrm{kg}$ ). All the samples contained levels below the recommended EU limits.

A high amount of DON was documented in wheat and cereal samples from Austria, Germany, Slovakia and Australia [28] (42 to $4130 \mu \mathrm{g} / \mathrm{kg}$ with an average amount of $977 \pm 1000 \mu \mathrm{g} / \mathrm{kg}$ ). In Cameroon, Njobeh et al. [29] documented that $65 \%$ of 82 samples 
of dried food commodities contained DON levels ranging from 13 to $273 \mu \mathrm{g} / \mathrm{kg}$. The occurrence and maximum amount of DON found in corn by Paladin et al. [30] in Croatia were higher than the levels found in the current study. They reported that $85 \%$ of samples were positive, with the highest concentration being 17,920 $\mu \mathrm{g} / \mathrm{kg}$. In Portugal, Marques et al. [31] analyzed 307 samples of plant crops, with a mean DON concentration of $70 \mu \mathrm{g} / \mathrm{kg}$ and a maximum amount of $17,900 \mu \mathrm{g} / \mathrm{kg}$. Vidal et al. [32] from Spain observed DON in $42 \%$ of bran samples, with the highest amount being $6178 \mu \mathrm{g} / \mathrm{kg}$, and 13 samples (19\%) exceeded the EU's allowable limit. In Serbia, Jajić et al. [33] documented that $32 \%$ of corn samples were contaminated; in Hungary, $86 \%$ of samples were contaminated with DON [34].

However, earlier studies have documented low levels of DON compared to those in the present survey. Escobar et al. [3] from Spain analyzed 25 samples of corn oil with mean levels of DON at $31 \mu \mathrm{g} / \mathrm{kg}$. Similarly, Giménez et al. [35], also from Spain, found 10 of 25 samples of wheat germ oil with mean levels of DON at $41 \mu \mathrm{g} / \mathrm{kg}$.

It is worth mentioning that regional variation was found in DON levels. Hot weather conditions promote the formation of fusarium-producing fungi and the production of mycotoxins [36]. The elevated prevalence of DON in corn and corn products in summer compared to winter was confirmed in our previous study [17]. Fernandez et al. [37] from the United States documented DON levels in cereal samples that were lower than the levels reported by Ngoko et al. [38] in corn from Cameroon. Temperate conditions favor the production of DON [39]. Furthermore, high levels of humidity combined with high temperature could enhance the growth rate of fungi belonging to the genus Fusarium [40]. Variation in sampling size is another factor that should be considered a significant source of variation in mycotoxins [41]. The elevated amount of DON in corn and corn products could be explained by farmers in Pakistan still using traditional methods in rural areas with cheap varieties of corn and not using crop rotation or a no-till method. Furthermore, the storage of corn in mud bins could enhance the contamination of cereal crops [42].

\subsection{Exposure Assessment of DON in Corn Flour}

In our previous study, by Iqbal et al. [18], the maximum DON exposure observed in wheat flour in summer was $8.8 \mu \mathrm{g} / \mathrm{kg}$ bw/day. According to the WHO [43], if ADD is greater than the provisional maximum tolerable daily intake (PMTDI), then the potential for health risk exists. The individual or population may suffer a health risk if the hazard quotient $(\mathrm{HQ})>1$. The health risks are limited if individuals or a population are exposed to a level of DON less than 1, i.e., if $\mathrm{HQ}<1$. An exposure of $1.052 \mu \mathrm{g} / \mathrm{kg}$ bw $/$ day of DON was estimated in bread and toasts [44], comparable to the exposure of DON found in the current research. An exposure of 0.027 to $0.038 \mu \mathrm{g} / \mathrm{kg}$ bw / day was observed by Cano-Sancho et al. [45]. The current study's finding of a high HQ level of 1.11 in the Hafizabad and Sheikhupura districts could indicate serious risk factors for the local populations.

\section{Conclusions}

Evaluating the findings of this research and comparing them with the EU's limit for mycotoxins reflects that the prevalence and amounts of DON were comparatively high. About $7.5 \%$ of samples of corn and corn products were contaminated with DON at levels greater than the EU's suggested limits. The exposure and HQ amount of DON in corn and corn products were also high. Adopting good storage practices would reduce the level of DON in cereals because generally, in Pakistan, cereal crops are stored and transported in jute bags, which could absorb moisture from the environment or surface where the crop is stored. The recommendation could be to store these crops in polyethylene bags during transport and in the storage area. Furthermore, moisture, humidity and temperature should be controlled during the storage period, and farmers should use resistant crop varieties. In vivo study of DON levels in blood and urine from local consumers should be used to assess exposure and implement regulations. 


\section{Materials and Methods}

\subsection{Sampling}

The 1220 samples of corn and corn products (corn flour, sweet corn, corn bread, corn oil and popcorn) from three Punjab districts ( $n=449$ Gujranwala, $n=378$ Hafizabad, $n=393$ Sheikhupura) were collected from June 2018 to January 2019. A simple random methodology (each portion or lot has an equal chance to be included) was used for collecting samples of corn and corn products from farmers, markets and superstores. The gross samples were taken by hand and then homogenized and properly labeled. These three districts are well-known producers of corn in Punjab, Pakistan. Due to the high variability of fungi and mycotoxins in kernel samples, each sample size was not less than $2 \mathrm{~kg}$. Then, the kernel samples were mixed and ground in adequate particle size (Retsch, ZM 200, Haan, Düsseldorf, Germany). The lab sample portion was stored in plastic bags and kept in a freezer at $-20^{\circ} \mathrm{C}$.

\subsection{Chemicals and Reagents}

A pure standard of DON (100 mg/mL in ACN) from Sigma-Aldrich (St. Louis, MO, USA) was available in the lab (a food safety lab). High-grade purity ( $\geq 99 \%)$ solvents of acetonitrile, methanol and polyethylene glycol 8000 (PEG) were acquired from SigmaAldrich (Sigma-Aldrich, Lyon, France). The method's linearity was assessed with sevenpoint concentrations $(100,200,800,1600,3200,6400$ and $9000 \mu \mathrm{g} / \mathrm{kg}$ ) of DON and stored in capped vials at a temperature of $-20^{\circ} \mathrm{C}$. All other chemicals used were of analytical grade and available in the lab.

\subsection{Extraction and HPLC Parameters}

The extraction of DON in corn and corn products was carried out using our previously validated method [17]. Briefly, the sample $(5 \mathrm{~g})$ and PEG $(1 \mathrm{~g})$ were mixed in $20 \mathrm{~mL}$ of ultrapure water, homogenized in $50 \mathrm{~mL}$ Teflon tubes and centrifuged at room temperature for $1 \mathrm{~min}$ at $6500 \mathrm{rpm}$. The extraction of corn bread was carried out by adding $200 \mathrm{~mL}$ water to dry bread and then homogenizing for $5 \mathrm{~min}$ at room temperature at $8000 \mathrm{rpm}$, as discussed above. After centrifugation, the mixture was filtered and the filtrate $(5 \mathrm{~mL})$ was passed through to the immunoaffinity column (IAC-NIV WB, columns) (VICAM, Watertown, MA, USA). The column was washed twice with $10 \mathrm{~mL}$ purified water, and the DON was eluted using $1 \mathrm{~mL}$ of pure methanol from the IAC column. Then, $0.5 \mathrm{~mL}$ of pure water was added to $0.5 \mathrm{~mL}$ of eluate and subjected to HPLC analysis, after passing through $0.22 \mu \mathrm{m}$ nylon syringe filters. The study used a Shimadzu (Kyoto, Japan) HPLC system with a C18 Supelco column $(250 \times 4.6 \times 5 \mathrm{~mm})$ (Discovery HS, Bellefonte, PA, USA). The UV detector (RF-530) was set at a detection wavelength of $218 \mathrm{~nm}$. The mobile phase was $30 \%$ methanol and $70 \%$ water, with a flow rate of $1.2 \mathrm{~mL} / \mathrm{min}$.

\subsection{Exposure Assessment}

According to the literature, the level of DON found in food in the present study is considered reasonable. Further, it was believed that exposure to DON was only through corn flour, this being the main ingredient in the Pakistani diet. The mean and highest levels of DON in corn flour were used to assess exposure, and an adult body weight is regarded as $65 \mathrm{~kg}$ bw. The per capita consumption of corn flour was $0.07 \mathrm{~kg}$ [1]. The exposure was assessed using the formula of Equation (1):

$$
\mathrm{ADD}_{\mathrm{DON}}=\frac{C D O N \times I R}{b w}
$$

where $\mathrm{ADD}_{\mathrm{DON}}$ is the average daily dose of $\mathrm{DON}, C_{D O N}$ is the concentration of $D O N$ in corn flour, $I R$ is the intake rate of corn flour and $b w$ is body weight.

The hazard quotient (HQ) values for the mean and highest levels of DON in corn flour were also estimated and equaled to exposure assessment studies. The provisional 
maximum tolerable daily intake (PMTDI) was $1 \mu \mathrm{g} / \mathrm{kg}$ bw for DON [20]. The HQ was determined following the formula shown in Equation (2):

$$
\mathrm{HQ}=\frac{\mathrm{ADD} D O N}{P M T D I}
$$

\subsection{Method Validation}

All the method validation parameters were performed for the assessment of DON in corn and corn products. The recovery analysis was performed. The fortified levels (100, $150,300,400,800,3000 \mu \mathrm{g} / \mathrm{kg}$ ) of DON were added in uncontaminated samples of corn and corn product samples. The LOD and LOQ were assessed as 3:1 and 10:1 signal-to-noise ratios, respectively.

\subsection{Statistical Analysis}

The results of DON levels in corn and corn products were subjected to statistical analysis using SPSS (version 26 for Windows, SPSS Inc., Chicago, USA). The DON levels in different corn samples and from different locations were checked for normal distribution (Shapiro-Wilks test). ANOVA was applied to investigate the difference of means (DON levels) between different types of corn and corn products and from different locations. The least significant difference (LSD) was used to investigate differences within each type or each location. A probability value of 0.05 was used to determine the statistical significance.

Supplementary Materials: The following are available online at https:/ / www.mdpi.com/article/10 .3390 / toxins13050296/s1, Figure S1: The standard curve of DON.

Author Contributions: Conceptualization, supervision, writing-original draft preparation, writing-review and editing: S.Z.I.; software, funding acquisition, review and editing: A.F.A.R.; resources: S.U. and N.B.A.; visualization, validation, formal analysis: M.R.A. All authors have read and agreed to the published version of the manuscript.

Funding: The research was funded by Higher Education Commission, Islamabad, Pakistan, with grant no. NRPU-8025. The APC was provided by The Universiti Putra Malaysia, Malaysia.

Institutional Review Board Statement: Not applicable.

Informed Consent Statement: Not applicable.

Data Availability Statement: The data will be available upon request.

Acknowledgments: The authors acknowledge the analytical facilities provided by NIAB, Faisalabad, Pakistan.

Conflicts of Interest: The authors declare no conflict of interest.

\section{References}

1. USDA. Pakistan: Grain and Feed Annual. GAIN Report Number: PK1707. 2017. Available online: https://www.fas.usda.gov/ data / pakistan-grain-and-feed-annual-3 (accessed on 24 January 2021).

2. Aniołowska, M.; Steininger, M. Determination of trichothecenes and zearalenone in different corn (Zea mays) cultivars for human consumption in Poland. J. Food Comp. Anal. 2014, 33, 14-19. [CrossRef]

3. Escobar, J.; Loran, S.; Gimenez, I.; Ferraz, E.; Herrera, M.; Herrera, A.; Arino, A. Occurrence and exposure assessment of Fusarium mycotoxins in maize germ, refined corn oil and margarine. Food Chem. Toxicol. 2013, 62, 514-520. [CrossRef] [PubMed]

4. Sweeney, M.J.; Dobson, A.D. Mycotoxin production by Aspergillus, Fusarium and Penicillium species. Int. J. Food Microbiol. 1998, 43, 141-158. [CrossRef]

5. Majeed, S.; Asi, M.R.; Iqbal, M.; Iqbal, S.Z.; Jinap, S. Analysis of nutritional traits and comparison of aflatoxins contamination in selected maize varieties from Pakistan. J. Food Prot. 2017, 80, 1993-1998. [CrossRef]

6. Iqbal, S.Z.; Asi, M.R.; Jinap, S. Detection of aflatoxins and zearalenone contamination in wheat-derived products. Food Control 2014, 35, 223-226. [CrossRef]

7. Agriopoulou, S.; Stamatelopoulou, E.; Varzakas, T. Advances in occurrence, importance and mycotoxin control strategies: Prevention and detoxification in foods. Foods 2020, 9, 137. [CrossRef]

8. Martins, H.M.; Almeida, I.; Marques, M.F.; Guerra, M.M. Fumonisins and deoxynivalenol in corn-based food products in Portugal. Food Chem. Toxicol. 2008, 46, 2585-2587. [CrossRef] 
9. Marasas, W.F.O. Toxigenic Fusaria. In Mycotoxins and Animal Foods; Smith, J.E., Ed.; CRS Press Inc.: Boston, MA, USA, 1991; pp. 216-252.

10. Tanaka, T.; Yamamoto, S.; Hasegawa, A.; Aoki, N.; Besling, J.R.; Sugiura, Y.; Ueno, Y. A survey of the natural occurrence of Fusarium mycotoxins, deoxynivalenol, nivalenol and zearalenone, in cereal harvested in the Netherlands. Mycopathologia 1990, 110, 19-22. [CrossRef]

11. Trucksess, M.W.; Thomas, F.; Young, K.; Stack, M.E.; Fulguers, W.J.; Page, S.W. Survey of deoxynivalenol in US 1993 wheat and barley crop by enzyme-linked-immunosorbent-assay. J. AOAC Int. 1995, 78, 631-636. [CrossRef]

12. Placenta, C.M.; D'Mello, J.P.F.; Macdonald, A.M.C. A review of worldwide contamination of cereal grains and animal feed with Fusarium mycotoxins. Animal Feed Sci. Technol. 1999, 78, 21-37. [CrossRef]

13. Iqbal, S.Z.; Rehman, B.; Jinap, S.; Akram, N.; Ahmad, M.N.; Sanny, M.; Sukor, R.; Samsudin, N.I. Assessment of fumonisin B1 concentrations in wheat and barley products in the Punjab region of Pakistan. J. Food Prot. 2020, 83, 1284-1288. [CrossRef]

14. Pestka, J.J.; Bondy, J.S. Alterations of immune function following dietary mycotoxin exposure. Can. J. Physiol. Pharmacol. 1990, 68, 1009-1016. [CrossRef]

15. Pestka, J.J.; Smolinski, A.T. Deoxynivalenol: Toxicology and potential effects on humans. J. Toxicol. Environ. Health Part B 2005, 8, 39-69. [CrossRef]

16. Hussein, H.S.; Brasel, J.M. Toxicity, metabolism and impact of mycotoxins on humans and animals. Toxicology 2001, 167, 101-134. [CrossRef]

17. Raza, H.M.F.; Asi, M.R.; Maqbool, U. Assessment of deoxynivalenol (don) mycotoxin in corn and wheat grains consumed in central Punjab, Pakistan. Pak. J. Bot. 2020, 52, 2205-2210. [CrossRef]

18. Iqbal, S.Z.; Usman, S.; Razis, A.F.A.; Ali, N.B.; Saif, T.; Asi, M.R. Assessment of deoxynivalenol in wheat, corn and products and estimation of dietary intake. Int. J. Environ. Res. Public Health 2020, 17, 5602. [CrossRef]

19. European Commission. Commission Regulation No. 1881/2006 of 19 December 2006 setting maximum levels for certain contaminants in foodstuff. Eur. J. Union 2006, 364, 5-24.

20. Iqbal, S.Z.; Asi, M.R.; Ariño, A.; Akram, N.; Zuber, M. Aflatoxin contamination in different fractions of rice from Pakistan and estimation of dietary intakes. Mycotoxin Res. 2012, 28, 175-180. [CrossRef]

21. Joint Food and Agriculture Organization/World Health Organization Expert Committee on Food Additives (JECFA). Evaluation of Certain Food Additives and Contaminants (Report of the 72nd Meeting of the Joint FAO/WHO Expert Committee on Food Additives (JECFA)); WHO Technical Report Series; WHO: Geneva, Switzerland, 2010; p. 958.

22. European Commission. Commission Regulation (EC) No. 401/2006 of 23 February 2006 laying down the methods of sampling and analysis for the official control of the levels of mycotoxins in foodstuffs. Eur. Comm. 2006, 70, 12-35.

23. Ok, H.E.; Lee, S.Y.; Chun, H.S. Occurrence and simultaneous determination of nivalenol and deoxynivalenol in rice and bran by HPLC-UV detection and immunoaffinity cleanup. Food Control 2018, 87, 53-59. [CrossRef]

24. Yang, D.; Geng, Z.M.; Ma, H.X.; Yao, J.B.; Zhang, X.; Zhang, P.P.; Zhang, P. Establishment of a HPLC-UV method for simultaneous determination of DON, $15 A c D O N$, and 3AcDON in wheat. Acta Agron. Sin. 2012, 38, 186-189. [CrossRef]

25. Thammawong, M.; Okabe, M.; Kawasaki, T.; Nakagawa, H.; Nagashima, H.; Okadome, H.; Nakajima, T.; Kushiro, M. Distribution of deoxynivalenol and nivalenol in milling fractions from Fusarium-infected Japanese wheat cultivars. J. Food Prot. 2010, 73, 1817-1823. [CrossRef]

26. Golge, O.; Kabak, B. Occurrence of deoxynivalenol and zearalenone in cereals and cereal products from Turkey. Food Control 2020, 110, 106982. [CrossRef]

27. Cerveró, M.C.; Castillo, M.Ã.; Montes, R.; Hernández, E. Determination of trichothecenes, zearalenone and zearalenols in commercially available corn-based foods in Spain. Rev. Iberoam. Micol. 2007, 24, 52-55. [CrossRef]

28. Berthiller, F.; Dall'asta, C.; Corradini, R.; Marchelli, R.; Sulyok, M.; Krska, R.; Adam, G.; Schuhmacher, R. Occurrence of deoxynivalenol and its 3- $\beta$-D-glucoside in wheat and maize. Food Addict. Contam. Part A 2009, 26, 507-511. [CrossRef]

29. Nobel, P.B.; Dutton, M.F.; Koch, S.H.; Chuturgoon, A.A.; Stoev, S.D.; Mosonik, J.S. Simultaneous occurrence of mycotoxins in human food commodities from Cameroon. Mycotoxin Res. 2010, 26, 47-57.

30. Paladin, J.; Sokolović, M.; Perši, N.; Zadravec, M.; Jaki, V.; Vulić, A. Contamination of maize with deoxynivalenol and zearalenone in Croatia. Food Control 2012, 28, 94-98. [CrossRef]

31. Marques, M.F.; Martins, H.M.; Costa, J.M.; Bernardo, F. Co-occurrence of deoxynivalenol and zearalenone in crops marketed in Portugal. Food Addict. Contam. Part B 2008, 1, 130-133. [CrossRef]

32. Vidal, A.; Marín, S.; Ramos, A.J.; Cano-Sancho, G.; Sanchis, V. Determination of aflatoxins, deoxynivalenol, ochratoxin A and zearalenone in wheat and oat-based bran supplements sold in the Spanish market. Food Chem. Toxicol. 2013, 53, 133-138. [CrossRef]

33. Jajić, I.; Jurić, V.; Glamočić, D.; Abramović, B. Occurrence of deoxynivalenol in maize and wheat in Serbia. Int. J. Mol. Sci. 2008, 9 , 2114-2126. [CrossRef]

34. Tima, H.; Brückner, A.; Mohácsi-Farkas, C.; Kiskó, G. Fusarium mycotoxins in cereals harvested from Hungarian fields. Food Addict. Contam. Part B 2016, 9, 127-131. [CrossRef] [PubMed]

35. Giménez, I.; Herrera, M.; Escobar, J.; Ferraz, E.; Lorán, S.; Herrera, A.; Ariño, A. Distribution of deoxynivalenol and zearalenone in milled germ during wheat milling and analysis of toxin levels in wheat germ and wheat germ oil. Food Control 2013, 34, 268-273. [CrossRef] 
36. Hirooka, E.Y.; Yamaguchi, M.M.; Aoyama, S.; Sugiura, Y.; Ueno, Y. The natural occurrence of fumonisins in Brazilian corn kernels. Food Addict. Contam. 1996, 13, 173-183. [CrossRef] [PubMed]

37. Fernandez, C.; Stack, M.E.; Musser, S.M. Determination of deoxynivalenol in 1991 in US winter and spring wheat by highperformance thin-layer chromatography. J. Assoc. Off. Anal. Chem. Int. 1994, 77, 628-630.

38. Ngoko, Z.; Marasas, W.F.O.; Rheeder, J.P.; Shephard, G.S.; Wingfield, M.J.; Cardwell, K.F. Fungal infection and mycotoxin contamination of maize in the humid forest and the western highlands of Cameroon. Phytoparacitica 2001, 29, 352-360. [CrossRef]

39. Devegowda, G.; Raju, M.V.; Nazar, A.; Swamy, H.V. Mycotoxin picture worldwide: Novel solutions for their counteraction. In Biotechnology in the Feed Industry. Proceedings of Alltech's 14th Annual Symposium; Nottingham University Press: Nottingham, UK, 1998; pp. 241-255.

40. Soriano, J.M.; Dragacci, S. Occurrence of fumonisins in foods. Food Res. Int. 2004, 37, 985-1000. [CrossRef]

41. Whitaker, T.B.; Truckess, W.M.; Johansson, A.S.; Giesbrecht, F.G.; Hagler, W.M., Jr.; Bowman, D.T. Variability associated with testing shelled corn for fumonisin. J. Assoc. Off. Anal. Chem. Int. 1998, 81, 1162-1168. [CrossRef]

42. Iqbal, S.Z.; Rabbani, T.; Asi, M.R.; Jinap, S. Assessment of aflatoxins, ochratoxin A and zearalenone in breakfast cereals. Food Chem. 2014, 157, 257-262. [CrossRef]

43. World Health Organization (WHO). Principles and Methods for the Risk Assessment of Chemicals in Food; World Health Organization: Geneva, Switzerland, 2009; Volume 240.

44. Raad, F.; Nasreddine, L.; Hilan, C.; Bartosik, M.; Parent-Massin, D. Dietary exposure to aflatoxins, ochratoxin A and deoxynivalenol from a total diet study in an adult urban Lebanese population. Food Chem. Toxicol. 2014, 73, 35-43. [CrossRef]

45. Cano-Sancho, G.; Ramos, V.; Marín, S.; Sanchis, V. Micotoxinas. Estudio de dieta Total en Cataluña 2008-2009; Generalitat de Cataluña: Barcelona, Spain, 2012; pp. 135-140. 